\title{
IAMJ
}

INTERNATIONAL

AYURVEDIC

MEDICAL JOURNAL

\section{AYURVEDIC MANAGEMENT OF SYSTEMIC LUPUS ERYTHEMATOSUS}

\author{
Vatsal Dhudashiya1, Radhikaba Zala ${ }^{2}$, Pooja B.A ${ }^{3}$, Sangamitra Pattnaik ${ }^{4}$ \\ ${ }^{1}$ House Surgeon at Sushrutha Ayurvedic Medical College and Hospital, Bangalore, Karnataka, India \\ ${ }^{2}$ House Surgeon at Sushrutha Ayurvedic Medical College and Hospital, Bangalore, Karnataka, India \\ ${ }^{3}$ Associate Professor, Department of Panchakarma, at Sushrutha Ayurvedic Medical College and Hospital, \\ Bangalore, Karnataka, India \\ ${ }^{4}$ Principal and HOD of Panchakarma, at Sushrutha Ayurvedic Medical College and Hospital, Bangalore, \\ Karnataka, India
}

Corresponding Author: drpoojaba@gmail.com

https://doi.org/10.46607/iamj3809122021

(Published Online: December 2021)

Open Access

(C) International Ayurvedic Medical Journal, India

Article Received: 10/11//2021 - Peer Reviewed: 07/12/2021 - Accepted for Publication 08/12/2021

\section{Check for updates}

\begin{abstract}
Systemic Lupus Erythematosus is a systemic autoimmune connective tissue disease. Arthralgia is a common symptom, occurring in $90 \%$ of patients, and is often associated with early morning stiffness. Considering symptomatology, In Ayurveda classics, it can be compared with amavata ${ }^{1}$. This is the case report of a female patient aged 19 years suffering from multiple joints pain associated with swelling and tenderness and finger deformities, Diagnosed as Systemic lupus erythematosus (SLE). Visited the Department of Panchakarma, SAMC\&H, Bangalore for the treatment. Virechana karma followed by Shamana Aushadhi was administered. Significant improvement in the signs and symptoms was observed clinically.
\end{abstract}

Keywords: Systemic Lupus Erythematosus, SLE, Amavata, Virechana, Shamana Auaushadhi

\section{INTRODUCTION}

Systemic Lupus Erythematosus (SLE) is an autoimmune disease in which organs and cells undergo damage mediated by tissue binding autoantibodies and immune complexes. ${ }^{2}$ Some $90 \%$ of affected pa- 
tients are female and the peak age at onset is between 20 and 30 years. $^{3}$ Based on the clinical signs and symptoms of above said patient this can be correlated to Amavata of Ayurveda classics. Interactions between susceptibility genes and environmental factors result in abnormal immune responses. Several environmental stimuli may influence SLE. Exposure to ultraviolet light causes flares of SLE in approximately $70 \%$ of patients. ${ }^{4}$ SLE has relapsing and remitting phase. Treatment is aimed at controlling acute, severe flares and then developing maintenance strategies that suppress symptoms to an acceptable level and prevent organ damage. In Ayurveda, as Amavata is having bahudosha lakshanas hence shodhana is the best line of treatment.

\section{Case Report:}

A 19-year-old female patient visited our Panchakarma OPD with chief complaints of multiple joints pain associated with swelling and tenderness. Along with these complaints she reported deformities on fingers and general malaise.

\section{History of Present Illness:}

The patient was said to be normal before 8 years, later she developed fever and multiple joint pain. Gradually finger deformities developed. Fever use to start by evening and gradually increases during the night and comes down by morning which was accompanied by multiple joints pain. Then she visited a nearby higher medical centre and was diagnosed with SLE in 2014 and prescribed the following medication:

1. Tab wysolone $7.5 \mathrm{mg}(1-0-0)$

2. Tab HCQS $200 \mathrm{mg}(1-0-0)$

3. Tab MMF $500 \mathrm{mg}$ (mycophenolate mofetil) (2-0-2).
With these medicines, she found slight relief. When medications were stopped periodic flare-up of pain used to develop. In 2019 she developed weakness and fatigue for which she got admitted to the hospital and found that $\mathrm{Hb} \%$ was on the lower side so immediately blood transfusion was done, and the patient become stable. As the patient did not get much relief in joint pain and her symptoms so she visited our OPD and later she got admitted to our IPD for further treatment.

Personal History: Bowel: clear, Appetite: good, Micturition: normal frequency, Sleep: disturbed, Family History: No supportive family history, in this case, was found., Ashtavidha Pariksha:, Nadi: 82/min, Mala: Prakrut, Mutra: Prakrut, Jihwa: Alipta, Sparsha: Anushnashita, Drik: prakrut , Akriti: Kashaya asyata, Dashavidha Pariksha: Prakruti: Pittavataja, Vikruti: Dosha - vata, Dooshya - rasa, rakta, asthi Satwa: Pravara, Sara: madhyama, Samhanana: avara, Pramana: avara, Satmya: sarva rasa, Aharashakti: madhyama, Vyayamashakti: avara, Vaya: 19 years

\section{Diagnostic Criteria:}

The diagnosis was based on American College of Rheumatology diagnostic criteria (ACR), 4 symptoms were present, which were:

1. Oral ulcer

2. Arthritis

3. Hematologic disorder

4. Antinuclear antibodies

\section{Assessment Criteria:}

1. DAS Score

2. SF-36

3. General health and disability index

4. Grading of sandhishoola (pain)

\begin{tabular}{|l|l|l|}
\hline Sr. no. & Severity of pain & Grade \\
\hline 1 & No pain & 0 \\
\hline 2 & Mild pain & 1 \\
\hline 3 & Moderate, but no difficulty in moving & 2 \\
\hline 4 & Severe, with difficulty in moving the body parts & 3 \\
\hline
\end{tabular}


5. Grading of Sandhishotha (swelling)

\begin{tabular}{|l|l|l|}
\hline Sr. no. & Severity of swelling & Grade \\
\hline 1 & No swelling & 0 \\
\hline 2 & Slight swelling & 1 \\
\hline 3 & Moderate swelling & 2 \\
\hline 4 & Severe swelling & 3 \\
\hline
\end{tabular}

6. Grading of Sparshaasahatwa (tenderness)

\begin{tabular}{|l|l|l|}
\hline Sr. no. & Severity of tenderness & Grade \\
\hline 1 & No tenderness & 0 \\
\hline 2 & The subjective experience of tenderness & 1 \\
\hline 3 & Wincing of the face on pressure & 2 \\
\hline 4 & Wincing of face and withdrawal of the affected part on the pressure & 3 \\
\hline
\end{tabular}

\section{Treatment protocol:}

The treatment was planned for-
A. Yukti vyapashraya: 1) Virechana 2) Shamana Aushadhi

B. Daiva vyapashraya: 1) Vishnu Sahasranamam chanting

\section{A. YUKTI VYAPASHRAYA:}

\section{VIRECHANA KARMA:}

\begin{tabular}{|c|c|c|c|}
\hline Sr, no. & Protocol & Medicine & Duration \\
\hline 1. & Deepana and pachana & $\begin{array}{l}\text { 1. Chitrakadi vati ( } 1 \text { tablet } 2 \text { times a day before food with luke- } \\
\text { warm water) } \\
\text { 2. Aganitundi vati ( } 1 \text { tablet } 2 \text { times a day after food with luke- } \\
\text { warm water.) }\end{array}$ & 3 days \\
\hline 2. & Snehapana & 1. Indukantam ghritam ( $25 \mathrm{ml}$ to $100 \mathrm{ml})$ & 4 days \\
\hline 3. & Mrudu abhyana and swedana & 1. Kshreerabala taila & 4 days \\
\hline 4. & Virechana & 1. Trivrut lehya $30 \mathrm{gms}$ & 1 day \\
\hline 5. & Samsarjana krama & $\begin{array}{l}\text { 1. Peya (liquid gruel) } \\
\text { 2. Vilepi (gruel) } \\
\text { 3. Yusha (green gram soup) } \\
\text { 4. Odana (rice) }\end{array}$ & 3 days \\
\hline
\end{tabular}

- Observation on the day of Virechana karma:

\begin{tabular}{|l|l|l|}
\hline Sr. no. & Observations & Result \\
\hline 1 & Vegiki & 7 vegas \\
\hline 2 & Antiki & Kaphant Virechana \\
\hline
\end{tabular}

\section{SHAMANA AUSHADHI:}

\begin{tabular}{|l|l|l|}
\hline Sr. No. & Medicine & Dose \\
\hline 1 & Amrutadi Guggulu & $1-0-1$ (A.F.) \\
\hline 2 & Tab. Rhukot & $1-0-1$ (A.F.) \\
\hline 3 & Aragwadha amrutadi kashayam & $10 \mathrm{ml}-0-10 \mathrm{ml}$ (B.F.) \\
\hline 4 & Flexfen liniment & (External application) \\
\hline
\end{tabular}




\section{B. DAIVA VYAPASHRAYA:}

\section{VISHNU SAHASRANAMAM:}

The patient was recommended to chant vishnusahasranamam as a form of psychological treatment.

Follow up: The patient was asked to revisit after 1 month.

\section{Observation and Result:}

Prescribed Ayurvedic treatment helped in managing the progressive signs and symptoms of the disease. Joints pain, tenderness and swelling is reduced. Improvement in performing day to day life activities was noted. The overall quality of life is improved.

1. Functional Improvement is noted in DAS Score, SF-36, General health and disability index after treatment.

2. Assessment of sandhi shoola (pain)

\begin{tabular}{|l|l|l|l|l|}
\hline Left & Name of joint & Right \\
\hline before & after & & before & after \\
\hline 3 & 1 & Parvasandhi & 3 & 1 \\
\hline 2 & 0 & Manibandha & 2 & 1 \\
\hline 1 & 0 & Kurpara sandhi & 2 & 0 \\
\hline 0 & 0 & Amsa sandhi & 1 & 0 \\
\hline 2 & 0 & Gulpha sandhi & 3 & 1 \\
\hline 0 & 0 & Janusandhi & 2 & 0 \\
\hline
\end{tabular}

5. Assessment of sandhi shotha (swelling)

\begin{tabular}{|l|l|l|l|l|}
\hline Left & Name of joint & Right & \\
\hline before & after & & before & after \\
\hline 1 & 0 & Janusandhi & 2 & 0 \\
\hline 0 & 0 & Kurpara sandhi & 2 & 0 \\
\hline
\end{tabular}

6. Assessment of sparshaasahatwa (tenderness)

\begin{tabular}{|l|l|l|l|l|}
\hline Left & Name of joint & Right & \\
\hline before & after & before & after \\
\hline 2 & 0 & Parvasandhi & 3 & 1 \\
\hline 2 & 0 & Manibandha & 2 & 1 \\
\hline 0 & 0 & Kurpara sandhi & 1 & 0 \\
\hline 0 & 0 & Amsa sandhi & 1 & 0 \\
\hline 2 & 1 & Gulpha sandhi & 3 & 1 \\
\hline 1 & 0 & Janusandhi & 2 & 0 \\
\hline
\end{tabular}

\section{DISCUSSION}

SLE is one of the commonest autoimmune diseases, presenting with clinical symptoms like fever, arthralgia, myalgia, fatigue, proliferative glomerulonephritis and cutaneous manifestations. Having prevalence of 15-50 per 100,000. Similar symptoms have been explained under the heading of Amavatarogaadhikara in Madhavanidana. like jwara, aruchi, angamarda, sandhishoola, sandhi shotha etc. ${ }^{5}$ Considering the prognosis and limitations in the line of treatment virechana karma were administered methodically, as text quotes: "जिताः संशोधनैर्ये तु न तेषां पुनरुद्दवः"6 by the administration of shodhana treatment it acts at root levels and does correction of dooshyas and elimination of vitiated dosha out of the body. As asthi and sandhi involvement is seen in this disease followed by deepana pachana, Indukanta ghrita was selected for snehapana further as the patient was bala, suku- 
mara, avara sharira bala mrudu abhyanga with swedana was given for 4 days. Further, as Trivrut is considered sukha virechaka dravya, 30 gms of compound formulation that is Trivrutlehya was administered. After the procedure by assessing vegiki and antiki lakshana patient was advised with samsarjana krama.

The further patient was asked to continue Amruthadi guggulu, Aragwadha amrutadi kashayam, Flexofen liniment and tab. Rhukot as all this is going to alleviate the symptoms of Amavata. Along with the above treatment, as a part of psychological treatment patient was told to chant Vishnu sahasranamam as daivavyapashraya chikitsa.

\section{CONCLUSION}

A female patient aged 19 years diagnosed with SLE compared to Amavata as per Ayurveda classics was treated with Virechana and Shamana aushadhi effectively. Significant improvement was observed in the patient so Virechana along with Shamana aushadhi is found to be clinically effective in the management of signs and symptoms of SLE.

\section{Acknowledgement:}

We feel highly grateful to Dr Pooja B. A. Associate professor, Department of Panchakarma, Sushrutha Ayurvedic medical college and hospital, Bangalore for valuable guidance during this case study.

\section{REFERENCES}

1. Chakrapani Datta, Chakradatta, translated by Ayurvedacharya Pandit Jagannathasarma Bajpeyee, Amavatadhikara, chapter 25, Published by The Proprietor, Shri Laxmi Venkateshwar steam press, Bombay, 3rd edition; Pp. 131

2. J. Jameson, A. Fauci, D. kasper, S. Hauser, D. Longo, J. Loscalzo, Harrison's principles of internal medicine, 20th Intern edition 2018. Published by McGraw-Hill Education. chapter number: 349, Pp. 2515.

3. S. Ralston, I. Penman, M. Strachan, R. Hobson, Davidson's Principles and Practice of Medicine, $23^{\text {rd }}$ Edition 2018, Published Elsevier Limited, chapter number: 24, Pp. 1034.

4. J. Jameson, A. Fauci, D. kasper, S. Hauser, D. Longo, J. Loscalzo, Harrison's principles of internal medicine, 20th Intern edition 2018. Published by McGraw-Hill Education. chapter number: 349, Pp. 2516.

5. Madhavakara, Madhava Nidanam, translated by Prof. K. R. Srikantha Murthy, $25^{\text {th }}$ chapter $/ 6^{\text {th }}$ verse, Published by Chaukhambha Orientalia, Varanasi, 2016 edition: Pp. 95.

6. Agnivesha, Charaka samhita, Ayurveda deepika commentary by chakrapani, Sutra sthana; $16^{\text {th }}$ chapter $/ 20^{\text {th }}$ verse, Published by Chaukhambha Orientalia, Varanasi, 2015 edition; Pp. 97.

\section{Source of Support: Nil \\ Conflict of Interest: None Declared}

How to cite this URL: Vatsal Dhudashiya et al: Ayurvedic Management Of Systemic Lupus Erythematosus. International Ayurvedic Medical Journal \{online\} 2021 \{cited December 2021\} Available from: http://www.iamj.in/posts/images/upload/3158_3162.pdf 